\title{
Photoresponsive Change of the Surface Potential Generated by Helical Peptide Self-Assembled Monolayers
}

\author{
Yasuhiko TADA, ${ }^{1}$ Tomoyuki Morita, ${ }^{1}$ Junzo UMEMURA, ${ }^{2}$ \\ Mitsumasa IwAmoto, ${ }^{3}$ and Shunsaku KImURA ${ }^{1, \dagger}$ \\ ${ }^{1}$ Department of Material Chemistry, Graduate School of Engineering, Kyoto University, \\ Kyoto-Daigaku-Katsura, Nishikyo-ku, Kyoto 615-8510, Japan \\ ${ }^{2}$ Institute for Chemical Research, Kyoto University, Gokanosho, Uji 611-0011, Japan \\ ${ }^{3}$ Department of Physical Electronics, Tokyo Institute of Technology, \\ 2-12-1 O-okayama, Megruo-ku, Tokyo 152-8852, Japan
}

(Received March 28, 2005; Accepted May 16, 2005; Published August 15, 2005)

\begin{abstract}
Photoresponsive helical peptides, which are composed of two helical peptide segments with an intervening azobenzene unit, were synthesized, and the self-assembled monolayers (SAMs) were formed on gold. The helical peptides were shown to take vertical orientation on gold by Fourier transform infrared reflection-absorption spectroscopy, and to change the molecular orientation reversibly upon UV and visible light irradiation due to photoisomerization of the azobenzene unit. The structural changes upon photoirradiation resulted in alterations of the surface potential of the peptide SAMs. The helical peptides in the SAM are suggested to change the molecular orientation in a cooperative manner upon photoirradiation. [DOI 10.1295/polymj.37.599]

KEY WORDS Helix Peptide / Surface Potential / Photoresponse / Self-assembled Monolayer / Azobenzene /
\end{abstract}

Self-assembled monolayers (SAMs) of organic molecules have attracted much attention due to the regular structure on the nanometer scale, ${ }^{1}$ and organic molecules may replace the silicon-base devices in future when the miniaturization by the top-down method will face the physical limit and the change in the principle of operation of the electronic devices. ${ }^{2}$ Since proteins elicit various functions in the living system such as photoenergy harvest, electron transfer, and energy conversion, polypeptides as a model of proteins are convincing starting compounds for the molecular devices. ${ }^{3}$

Helical peptides have been extensively studied as a model of protein secondary structure. Their regular structure is formed by intramolecular hydrogen bonds between the amide proton at the 5th residue and the carbonyl oxygen at the 1st residue. The molecular alignment of peptide bonds along the helix generates a large dipole moment. ${ }^{4}$ Notably, helices tend to self-assemble into a bundle structure, which is often crucial for the protein functions such as ion-channel formation. Using this property of self-assembling of helices, self-assembled monolayers (SAMs) of the helical peptides on gold have been reported..$^{5}$ The peptide SAMs have been investigated mainly from two aspects: mediator for electron transfer at a long distance $^{5}$ and generation of surface potential. ${ }^{6}$ Both aspects are strongly related with the large dipole moment along the helix.
When the helical peptides are immobilized via the $\mathrm{C}$ terminal and the $\mathrm{N}$ terminals are exposed to the surface, positive surface potential is generated due to the positive partial charge on the $\mathrm{N}$ terminal. ${ }^{6}$ Since the intensity of the surface potential is a function of the dipole moment, change of helix orientation on gold should results in change of surface potential of the helix SAM. In the present study, we have synthesized novel helical peptides having two $\alpha$-helical segments with an intervening azobenzene unit (Figure 1, Nunchaku peptide and Nunchaku Type-L). The azobenzene unit is well known to isomerize reversibly upon UV and visible light irradiation. The azobenzene-containing helix peptide SAM should therefore show photoresposive change of the surface potential due to the molecular orientation change. The two helix segments of the Nunchaku peptide are designed to take the opposite helix sense. Layer-by-layer structure, where the helix layer at the top of the SAM is formed above the helix layer at the bottom with a intervening layer of azobenzene, may be promoted in the Nunchaku peptide SAM by using the phase separation property according to the difference of the helical sense.

\section{EXPERIMENTAL}

\section{Materials \\ DL-6,8-Thioctic amide (DL-6,8-lipoamide) was pur-}

${ }^{\dagger}$ To whom correspondence should be addressed (E-mail: shun@scl.kyoto-u.ac.jp). 

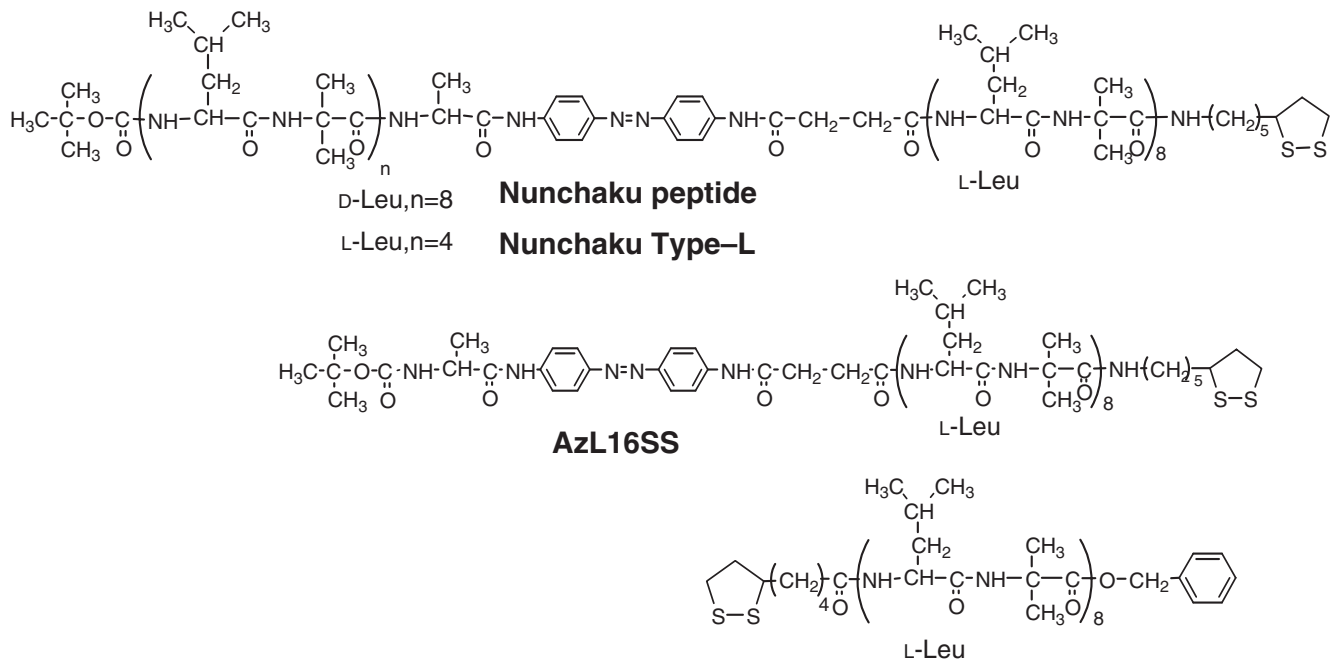

SSL16B

Figure 1. Molecular structures and abbreviations of the peptide derivatives.

chased from Tokyo Kasei Inc., and 4,4'-diaminoazobenzene was obtained from Lancaster Inc.

Nunchaku peptide, Nunchaku Type-L, and AzL16SS were synthesized by the conventional liquid phase method using a fragment condensation technique (Scheme 1). BL16B and SSL16B were synthesized according to the method reported previously. ${ }^{7}$ All synthetic products were analyzed by ${ }^{1} \mathrm{H}$ NMR $(400 \mathrm{MHz})$, and the purity was checked by thin layer chromatography (TLC, silica gel $60 \mathrm{~F}_{254}$ aluminum plate, Merck Co.) with using the following solvent systems: (A) chloroform/methanol/acetic acid $\mathrm{v} / \mathrm{v} / \mathrm{v}=95 / 5 / 3$, (B) chloroform $/$ methanol/pyridine $\mathrm{v} / \mathrm{v} / \mathrm{v}=95 / 5 / 3$, (C) chloroform/methanol/ammonia $(28 \%) \quad \mathrm{v} / \mathrm{v} / \mathrm{v}=13 / 5 / 1$, (D) chloroform/methanol $\mathrm{v} / \mathrm{v}=8 / 1$, (E) chloroform $/$ methanol $\mathrm{v} / \mathrm{v}=5 / 1$.

$B a A z(D-A l a)$. Boc-D-Ala-OH (400 mg), O-(7-Azabenzotriazol-1-yl)-1,1,3,3-tetramethyluronium hexafluorophosphate (HATU, $968 \mathrm{mg}$ ), and $N, N$-diisopropylethylamine (DIEA, $1.03 \mathrm{~mL}$ ) in DMF $(10 \mathrm{~mL}$ ) was added to $4,4^{\prime}$-diaminoazobenzene $(450 \mathrm{mg})$ in DMF $(1 \mathrm{~mL})$ in a dropwise way at $0^{\circ} \mathrm{C}$. The solution was kept at $0^{\circ} \mathrm{C}$ for $3 \mathrm{~h}$, and stirred another $15 \mathrm{~h}$ at room temperature. The solution was condensed under reduced pressure, and the residue was dissolved in ethyl acetate. The organic phase was washed with $\mathrm{NaHCO}_{3}$ aq (2 times) and $\mathrm{NaCl}$ aq (2 times), and was dried and concentrated. The residual solid was purified by an LH-20 column using methanol as eluant. The produce was washed with diethyl ether. Yield: $291 \mathrm{mg}(36 \%)$ TLC: $\mathrm{R}_{\mathrm{f}}(\mathrm{A})=0.40$.

${ }^{1} \mathrm{H}$ NMR $(400 \mathrm{MHz}$, chloroform- $d$ ): $\delta$ (ppm) 1.45 $\left(3 \mathrm{H}, \mathrm{d}, \mathrm{AlaC}^{\beta} \mathrm{H}_{3}\right), 1.48\left(9 \mathrm{H},\left(\mathrm{CH}_{3}\right)_{3} \mathrm{C}\right), 4.33(1 \mathrm{H}, \mathrm{m}$, $\left.\mathrm{AlaC}^{\alpha} H\right), 4.96(1 \mathrm{H}, \mathrm{AlaNH}), 6.73,7.64,7.78,7.83$ $\left(8 \mathrm{H}\right.$, brm, $\left.\mathrm{C}_{6} \mathrm{H}_{4}\right), 8.63\left(1 \mathrm{H}, \mathrm{NHC}_{6} \mathrm{H}_{4} \mathrm{NN}\right)$.

$B A A z(L-A l a)$. BAAz was synthesized by the meth- od similarly to BaAz.

Yield: $45.0 \%$ TLC: $\mathrm{R}_{\mathrm{f}}(\mathrm{D})=0.62$.

${ }^{1} \mathrm{H}$ NMR $\left(400 \mathrm{MHz}\right.$, methanol- $\left.d_{4}\right): \delta(\mathrm{ppm}) 1.38$ $\left(3 \mathrm{H}, \mathrm{d}, \mathrm{AlaC}^{\beta} \mathrm{H}_{3}\right), 1.45\left(9 \mathrm{H},\left(\mathrm{CH}_{3}\right)_{3} \mathrm{C}\right), 4.21(1 \mathrm{H}, \mathrm{m}$, $\left.\mathrm{AlaC}^{\alpha} H\right), 6.73,7.67-7.77\left(8 \mathrm{H}, \mathrm{brm}, \mathrm{C}_{6} H_{4}\right)$.

$\mathrm{BaAzCOOH}(\mathrm{D}-\mathrm{Ala})$. BaAz (291 mg) and succinic anhydride (414 mg) were dissolved in pyridine $(5 \mathrm{~mL})$, and the solution was stirred at $50^{\circ} \mathrm{C}$ for $22 \mathrm{~h}$. The solution was evaporated, and the residue was dissolved in ethyl acetate. The product was extracted by $\mathrm{NaHCO}_{3}$ aq (3 times), and the aqueous solution was acidified by $\mathrm{KHSO}_{4}$ aq to extract the product with ethyl acetate. The organic phase was washed by $\mathrm{NaCl}$ aq and dried over $\mathrm{MgSO}_{4}$. After condensation, the solid was obtained. Yield: $312 \mathrm{mg}$ $(85 \%)$ TLC: $\mathrm{R}_{\mathrm{f}}(\mathrm{B})=0.03$.

${ }^{1} \mathrm{H}$ NMR $\left(400 \mathrm{MHz}, \mathrm{DMSO}-d_{6}\right): \delta(\mathrm{ppm}) 1.26(3 \mathrm{H}$, d, $\left.\mathrm{AlaC}^{\beta} \mathrm{H}_{3}\right), 1.37\left(9 \mathrm{H},\left(\mathrm{CH}_{3}\right)_{3} \mathrm{C}\right), 2.54,2.60(4 \mathrm{H}, \mathrm{m}$, $\left.\mathrm{CH}_{2} \mathrm{CH}_{2}\right), 4.12\left(1 \mathrm{H}, \mathrm{m}, \mathrm{AlaC}^{\alpha} H\right), 7.16(1 \mathrm{H}, \mathrm{d}$, AlaNH), 7.77-7.85 (8H, brm, $\left.\mathrm{C}_{6} \mathrm{H}_{4}\right), 10.3(2 \mathrm{H}, \mathrm{NH}-$ $\left.\mathrm{C}_{4} \mathrm{H}_{6}\right), 12.1(1 \mathrm{H}, \mathrm{bs}, \mathrm{COOH})$.

MS (FAB, matrix; nitrobenzyl alcohol): $\mathrm{m} / \mathrm{z} 484$ (calcd for $\mathrm{C}_{24} \mathrm{H}_{30} \mathrm{~N}_{5} \mathrm{O}_{6}[\mathrm{M}+\mathrm{H}]^{+}$484) $\mathrm{m} / z 506$ (calcd for $\mathrm{C}_{24} \mathrm{H}_{29} \mathrm{~N}_{5} \mathrm{O}_{6} \mathrm{Na}[\mathrm{M}+\mathrm{Na}]^{+}$506)

$B A A z C O O H(L-A l a)$. BAAzCOOH(L-Ala) was synthesized by the method similarly to $\mathrm{BaAzCOOH}$ (DAla).

Yield: $67 \mathrm{mg}(53 \%)$ TLC: $\mathrm{R}_{\mathrm{f}}(\mathrm{B})=0.21$.

${ }^{1} \mathrm{H}$ NMR $\left(400 \mathrm{MHz}\right.$, DMSO-$\left.d_{6}\right): \delta(\mathrm{ppm}) 1.27(3 \mathrm{H}$, $\left.\mathrm{d}, \mathrm{AlaC}^{\beta} \mathrm{H}_{3}\right), 1.38\left(9 \mathrm{H},\left(\mathrm{CH}_{3}\right)_{3} \mathrm{C}\right), 2.54,2.60(4 \mathrm{H}$, m, $\left.\mathrm{CH}_{2} \mathrm{CH}_{2}\right), 4.15\left(1 \mathrm{H}, \mathrm{m}, \mathrm{AlaC}^{\alpha} H\right), 7.15(1 \mathrm{H}, \mathrm{d}$, AlaNH), 7.80-7.83 (8H, brm, $\left.\mathrm{C}_{6} H_{4}\right), 10.3(2 \mathrm{H}, \mathrm{NH}-$ $\left.\mathrm{C}_{4} \mathrm{H}_{6}\right), 12.2(1 \mathrm{H}, \mathrm{bs}, \mathrm{COOH})$.

TFA.HL16SS. Trifluoroacetic acid $(0.5 \mathrm{~mL})$ was added to a chloroform solution $(0.5 \mathrm{~mL})$ of BL16SS $(45 \mathrm{mg})$. After $30 \mathrm{~min}$, the solution was evaporated, 


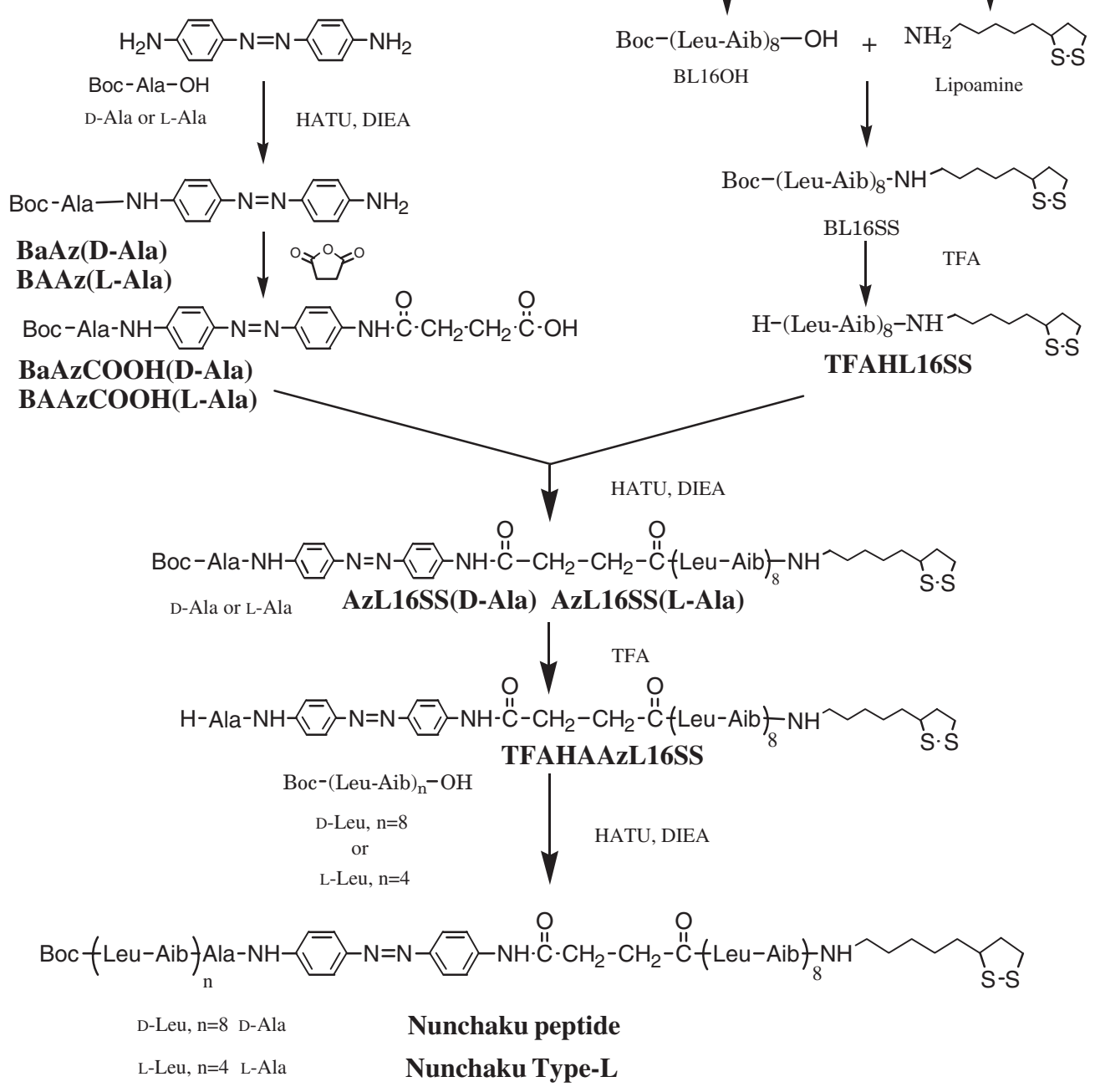

Scheme 1.

and the residual solid was treated with $n$-hexane. AzL16SS(D-Ala)

A DMF solution of HL16SS, BaAzCOOH (32 mg), HATU $(32 \mathrm{mg})$, and DIEA $(0.026 \mathrm{~mL})$ was stirred for $3 \mathrm{~h}$ at $0{ }^{\circ} \mathrm{C}$ under $\mathrm{N}_{2}$ atmosphere and for $21 \mathrm{~h}$ at room temperature. The solution was evaporated, and the residue was dissolved in chloroform and washed with $\mathrm{NaHCO}_{3}$ aq (3 times), NaClaq, $\mathrm{KHSO}_{4}$ aq (2 times), and NaClaq. After drying the chloroform layer with $\mathrm{MgSO}_{4}$, the solution was evaporated, and the residue was purified by an LH20 column using chloroform/ methanol $(1 / 1 \mathrm{v} / \mathrm{v})$ as eluant. Yield: $22 \mathrm{mg}(42 \%)$ TLC: $\mathrm{R}_{\mathrm{f}}(\mathrm{A})=0.44, \mathrm{R}_{\mathrm{f}}(\mathrm{E})=0.64$.

${ }^{1} \mathrm{H}$ NMR $\left(400 \mathrm{MHz}\right.$, methanol- $\left.d_{4}\right): \delta(\mathrm{ppm}) 0.80$ $0.93\left(48 \mathrm{H}, \mathrm{LeuC}^{\delta} \mathrm{H}_{3}\right), 1.40-1.90\left(92 \mathrm{H},\left(\mathrm{CH}_{3}\right)_{3} \mathrm{C}\right.$, Leu$\left.\mathrm{C}^{\beta} \mathrm{H}_{2}, \mathrm{LeuC}^{\gamma} \mathrm{H}, \mathrm{AibCH}_{3}, \mathrm{NHCH}_{2}\left(\mathrm{CH}_{2}\right)_{4}, \mathrm{AlaC}^{\beta} \mathrm{H}_{3}\right)$, $1.86,2.42\left(2 \mathrm{H}, \mathrm{m}, \mathrm{CHCH}_{2} \mathrm{CH}_{2} \mathrm{SS}\right), 2.51,2.71(4 \mathrm{H}$, m, $\left.\mathrm{CH}_{2} \mathrm{CH}_{2}\right), 3.08-3.19$ (4H, brm, $\mathrm{NHCH}_{2}\left(\mathrm{CH}_{2}\right)_{4}$, $\left.\mathrm{CHCH}_{2} \mathrm{CH}_{2} \mathrm{SS}\right), 3.53\left(1 \mathrm{H}, \mathrm{m}, \mathrm{CHCH}_{2} \mathrm{CH}_{2} \mathrm{SS}\right), 3.87$,

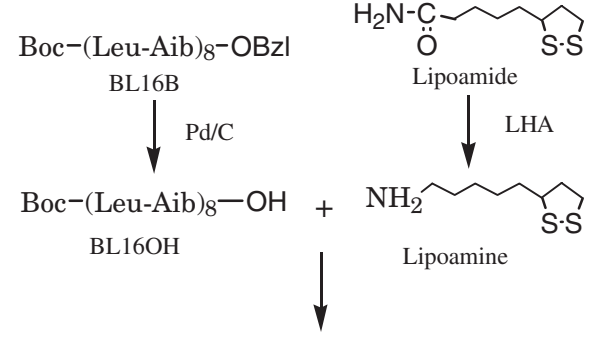

$\mathrm{Boc}-(\mathrm{Leu}-\mathrm{Aib})_{8}-\mathrm{NH}_{\mathrm{S} \cdot \mathrm{S}}$

TFAHL16SS 
MS (FAB, matrix; nitrobenzyl alcohol): $\mathrm{m} / \mathrm{z} 2241$ (calcd for $\mathrm{C}_{112} \mathrm{H}_{189} \mathrm{~N}_{22} \mathrm{O}_{21} \mathrm{~S}_{2}[\mathrm{M}+\mathrm{H}]^{+}$2242) $\mathrm{m} / \mathrm{z}$ 2264 (calcd for $\mathrm{C}_{112} \mathrm{H}_{188} \mathrm{~N}_{22} \mathrm{O}_{21} \mathrm{~S}_{2} \mathrm{Na} \quad[\mathrm{M}+\mathrm{Na}]^{+}$ 2264)

TFA.HAAzL16SS. TFA.HAAzL16SS was synthesized by the method similarly to TFA.HL16SS.

Nunchaku peptide. A DMF/chloroform $(1 / 1 \mathrm{v} / \mathrm{v})$ solution of TFA.HaAzL16SS, B116OH $(57 \mathrm{mg})$, HATU $(15 \mathrm{mg})$, and DIEA $(0.023 \mathrm{~mL})$ was stirred for $3 \mathrm{~h}$ at $0^{\circ} \mathrm{C}$ under $\mathrm{N}_{2}$ atmosphere and for $31 \mathrm{~h}$ at room temperature. The solution was evaporated, and the residue was dissolved in chloroform. The chloroform solution was washed with water, and was dried with $\mathrm{MgSO}_{4}$. The solution was evaporated, and the residue was purified by an LH20 column using chloroform/methanol $(1 / 1 \mathrm{v} / \mathrm{v})$ as eluant. The product was further purified by an LH60 column using chloroform/methanol $(1 / 1 \mathrm{v} / \mathrm{v})$ as eluant. Yield: $64 \mathrm{mg}$ (75\%) TLC: $\mathrm{R}_{\mathrm{f}}(\mathrm{D})=0.38$.

${ }^{1} \mathrm{H}$ NMR $\left(400 \mathrm{MHz}\right.$, methanol- $\left.d_{4}\right): \delta(\mathrm{ppm}) 0.64$ $0.93\left(48 \mathrm{H}\right.$, LeuC $\left.^{\delta} \mathrm{H}_{3}\right), 1.32-1.72\left(161 \mathrm{H},\left(\mathrm{CH}_{3}\right)_{3} \mathrm{C}\right.$, $\mathrm{LeuC}^{\beta} \mathrm{H}_{2}$, LeuC ${ }^{\gamma} \mathrm{H}$, AibCH $\mathrm{H}_{3}, \mathrm{NHCH}_{2}\left(\mathrm{CH}_{2}\right)_{4}$, Ala$\left.\mathrm{C}^{\beta} \mathrm{H}_{3}\right), 1.86,2.39\left(2 \mathrm{H}, \mathrm{m}, \mathrm{CHCH}_{2} \mathrm{CH}_{2} \mathrm{SS}\right), 2.48,2.68$ $\left(4 \mathrm{H}, \mathrm{m}, \mathrm{CH}_{2} \mathrm{CH}_{2}\right), 3.04-3.12\left(4 \mathrm{H}\right.$, brm, $\mathrm{NHCH}_{2}-$ $\left.\left(\mathrm{CH}_{2}\right)_{4}, \mathrm{CHCH}_{2} \mathrm{CH}_{2} \mathrm{SS}\right), \quad 3.64\left(1 \mathrm{H}, \quad \mathrm{m}, \quad \mathrm{CHCH}_{2}-\right.$ $\left.\mathrm{CH}_{2} \mathrm{SS}\right), 3.83,3.97,4.18,4.28\left(17 \mathrm{H}\right.$, brm, $\mathrm{LeuC}^{\alpha} \mathrm{H}$, $\left.\mathrm{AlaC}^{\alpha} H\right), 7.22(1 \mathrm{H}, \mathrm{d}, \mathrm{LeuNH}), 7.72-7.84(8 \mathrm{H}, \mathrm{brm}$, $\left.\mathrm{C}_{6} H_{4}\right), 8.03-8.23(34 \mathrm{H}$, LeuNH, AibNH, AlaNH, $\left.\mathrm{NHCH}\left(\mathrm{CH}_{2}\right)_{4}\right)$.

MS (FAB, matrix; nitrobenzyl alcohol): $m / z 3853$ (calcd for $\mathrm{C}_{192} \mathrm{H}_{322} \mathrm{~N}_{38} \mathrm{NaO}_{37} \mathrm{~S}_{2} \quad[\mathrm{M}+\mathrm{Na}]^{+} \mathrm{m} / \mathrm{z}$ 3850)

Nunchaku Type-L. Nunchaku Type-L was synthesized by the method similarly to Nunchaku peptide. Yield: $16 \mathrm{mg}(23 \%)$ TLC: $\mathrm{R}_{\mathrm{f}}(\mathrm{D})=0.38$.

${ }^{1} \mathrm{H}$ NMR (400 MHz, chloroform- $d$ ): $\delta(\mathrm{ppm}) 0.80$ $1.00\left(72 \mathrm{H}, \mathrm{LeuC}^{\delta} \mathrm{H}_{3}\right), 1.45-1.80\left(125 \mathrm{H},\left(\mathrm{CH}_{3}\right)_{3} \mathrm{C}\right.$, $\mathrm{LeuC}^{\beta} \mathrm{H}_{2}$, LeuC $\left.{ }^{\gamma} \mathrm{H}, \mathrm{AibCH}_{3}, \mathrm{NHCH}_{2}\left(\mathrm{CH}_{2}\right)_{4}\right), 1.85$, $2.42\left(2 \mathrm{H}, \mathrm{m}, \mathrm{CHCH}_{2} \mathrm{CH}_{2} \mathrm{SS}\right), 2.52,2.75\left(4 \mathrm{H}, \mathrm{m}, \mathrm{CH}_{2}-\right.$ $\left.\mathrm{CH}_{2}\right), 3.02-3.20\left(4 \mathrm{H}\right.$, brm, $\mathrm{NHCH}_{2}\left(\mathrm{CH}_{2}\right)_{4}, \mathrm{CHCH}_{2}-$ $\left.\mathrm{CH}_{2} \mathrm{SS}\right), 3.55\left(1 \mathrm{H}, \mathrm{m}, \mathrm{CHCH}_{2} \mathrm{CH}_{2} \mathrm{SS}\right), 3.90,4.00$, 4.20, $4.35\left(13 \mathrm{H}, \mathrm{brm}, \mathrm{LeuC}^{\alpha} H, \mathrm{AlaC}^{\alpha} H\right), 7.78-7.90$ $\left(8 \mathrm{H}, \mathrm{brm}, \mathrm{C}_{6} H_{4}\right), 7.25,7.43,7.97-8.28(27 \mathrm{H}, \mathrm{LeuNH}$, AibNH, AlaNH, $\left.\mathrm{NHCH}_{2}\left(\mathrm{CH}_{2}\right)_{4}\right)$.

MS (FAB, matrix; nitrobenzyl alcohol): $m / z 3059$ (calcd for $\mathrm{C}_{152} \mathrm{H}_{260} \mathrm{~N}_{30} \mathrm{O}_{29} \mathrm{~S}_{2} \mathrm{Na} \quad[\mathrm{M}+\mathrm{Na}]^{+} \mathrm{m} / z$ 3057)

\section{Preparation of Self-Assembled Monolayers}

Gold substrates for reflection-absorption spectroscopy and surface potential measurements were prepared by vapor deposition of chromium $(30 \mathrm{~nm})$ as adhesion layer and then gold $(99.99 \%, 200 \mathrm{~nm})$ on a slide glass $(76 \times 26 \mathrm{~mm})$. In the case of gold substrates for UV measurements, chromium $(1 \mathrm{~nm})$ and gold $(8 \mathrm{~nm})$ were successively deposited on quartz substrate $(38 \times 12 \mathrm{~mm})$.

SAMs were prepared by incubation of each gold substrate in an ethanol solution of the peptide $(0.1 \mathrm{mM})$ for $24 \mathrm{~h}$. The substrates were then washed by ethanol and dried under $\mathrm{N}_{2}$ gas. The bicomponent SAMs, Nunchaku/SSL16B $(1 / 1 \mathrm{~mol} / \mathrm{mol})$ and Nuchaku Type-L/SSL16B $(1 / 1 \mathrm{~mol} / \mathrm{mol})$, were prepared similarly.

\section{UV-vis Measurement}

UV-vis measurements were carried out on a Shimadzu UV-2450PC. Filters were used for UV irradiation, Toshiba UV-35 or UV-33, or visible light irradiation, Toshiba Vis-430, in combination with a Xe lamp (500 W, JASCO Co.).

\section{Fourier Transformed Infrared Reflection-absorption Spectroscopy (FTIR-RAS)}

FTIR-RAS measurements were performed on a Nicolet Magna 850 Fourier transformed infrared spectrophotometer with a Harrick Model RMA-1DG/ VRA reflection attachment. The incident light angle was set at $85^{\circ}$, and the number of interferogram accumulation was 500 .

The molecular orientation of the peptide monolayer on gold was determined on the basis of the amide I/ amide II absorbance ratio in the FTIR-RAS spectrum according to eq (1) under an assumption of a uniform distribution of the helical peptides along the surface normal. $^{5,6}$

$$
\frac{I_{1}}{I_{2}}=C \frac{2\left[\frac{1}{2}\left(3 \cos ^{2} \gamma-1\right)\right]\left[\frac{1}{2}\left(3 \cos ^{2} \theta_{1}-1\right)\right]+1}{2\left[\frac{1}{2}\left(3 \cos ^{2} \gamma-1\right)\right]\left[\frac{1}{2}\left(3 \cos ^{2} \theta_{2}-1\right)\right]+1}
$$

where $I_{i}, C, \gamma$, and $\theta_{i}$ (subscripts of 1 and 2 represent respectively amide I and II) represent the observed absorbance, the scaling constant $(C=1.5$ for the peptides), the tilt angle of the helix axis from the surface normal, and the angle between the transition moment of amide vibration mode and the helix axis, respectively. The values of $\theta_{1}$ and $\theta_{2}$ were taken to be $39^{\circ}$ and $75^{\circ}$, respectively.

\section{Surface Potential}

Surface potential of the peptide SAMs were measured by the Kelvin Probe technique with using a home-made apparatus under a high vacuum of $c a$. $10^{-6}$ torr. $^{8} \mathrm{Hg}$ lamp ( $200 \mathrm{~W}$, Hamamatsu LC5) with a filter (Sigma Koki, UTVAF-50S-33F) was used for UV irradiation on the SAMs, and Xe lamp $(500 \mathrm{~W}$, 

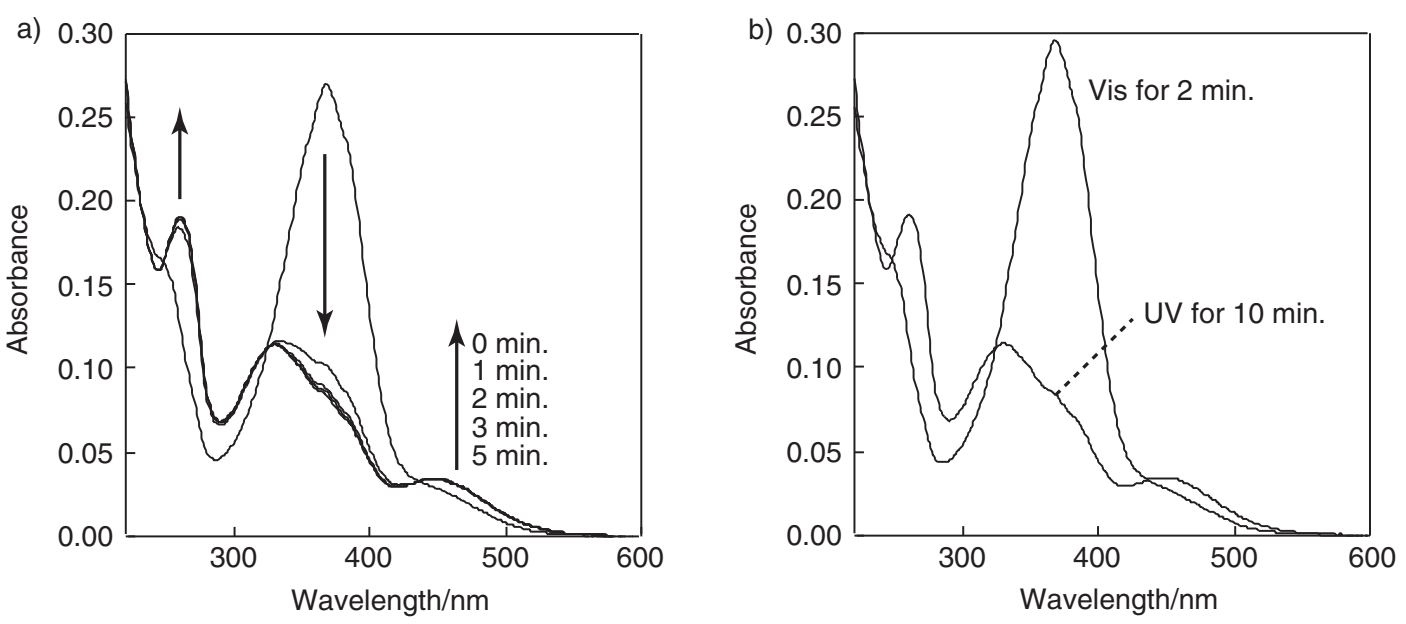

Figure 2. UV-vis absorption spectral change of Nunchaku peptide $\left(1.3 \times 10^{-5} \mathrm{M}\right)$ in ethanol upon; a) UV irradiation at $360 \mathrm{~nm}$. b) Vis irradiation for $10 \mathrm{~min}$ at $>430 \mathrm{~nm}$ after UV irradiation.

Ushio UI-501C) with a filter (Toshiba, Vis-430) was for visible light irradiation.

\section{Polarization-modulation IR-RAS (PMIR-RAS)}

PMIR-RAS measurements were performed on a Nicolet Magna 850 Frourier transform infrared spectrophotometer equipped with a Hinds Instruments PEM-90 photoelastic modulator system with a II/ ZS50 ZnSe head. The modulation frequency of this system was $2 \times 50=100 \mathrm{kHz}$. A GWC instruments SSD-100 synchronous sampling demodulator and Nicolet SST (simultaneous synchronous technique) module and software were used for signal processing. The incident light angle was set at $80^{\circ}$, and the accumulation number was 500. Filters were used for UV irradiation, Toshiba UV-35 or UV-33, and for visible light irradiation, Toshiba Vis-430, in combination with Xe lamp (350 W, Hamamatsu L2480).

\section{RESULTS AND DISCUSSION}

\section{Photoisomerization of the Peptides in Ethanol}

Photoisomerization of the Nunchaku peptide in an ethanol solution was analyzed by UV measurement (Figure 2). The absorption around $365 \mathrm{~nm}$ is assigned to the trans azobenzene unit $\left(\varepsilon=2.3 \times 10^{4}\right.$ $\left.\mathrm{M}^{-1} \mathrm{~cm}^{-1}\right),{ }^{9}$ and the intensity decreased significantly upon UV light irradiation. On the other hand, the small peak at $460 \mathrm{~nm}$, which appeared upon UV light irradiation, is assigned to the cis azobenzene unit. Since the UV spectrum after the visible light irradiation was the same as that before UV light irradiation, the azobenzene unit in the peptides photoisomerizes reversibly by UV and visible light irradiation. Nunchaku Type-L and AzL16SS also showed similar photoisomerization. Content of cis isomer after UV irradiation and isomerization rate were similar among these peptides in ethanol.

\section{Photoisomerization on Gold Substrate}

Photoisomerization of the peptide monolayer on gold was examined by UV measurement. ${ }^{10}$ The absorption around $370 \mathrm{~nm}$ due to the trans form of the azobenzene unit in the SAMs of Nunchaku peptide, Nunchaku Type-L, and AzL16SS decreased upon UV irradiation, and restored the intensity reversibly upon visible light irradiation (Figures $3 \mathrm{a}-\mathrm{c}$ ). The reversible photoisomerization was also observed with the bicomponent SAMs of Nunchaku peptide/SSL16B and Nunchaku Type-L/SSL16B (Figures 3d and e).

However, the cis contents after UV irradiation on the peptide SAMs were lower than those in ethanol, and decreased in the order of Nunchaku/ SSL16B $\quad(57 \%)>$ Nunchaku Type-L/SSL16B $(50 \%)>$ AzL16SS $(42 \%)>$ Nunchaku Type-L $(35 \%)>$ Nunchaku $(32 \%)$. This order indicates that the photoisomerization from trans to cis form occurs easily in the bicomponent SAMs, where the Nunchaku peptide or the Nunchaku Type-L are spaced out by the hexadecapeptide, SSL16B. The differences in the cis contents upon UV irradiation are thus explained in terms of the steric congestion around the azobenzene unit. The photoisomerization from trans to cis form should occur easily in the mixed SAMs, because the peptide segments in the top layer, which is located above the bottom hexadecapeptide layer connected just adjacent to gold, can move in the free space generated by the spacing of the inserted SSL16B in the bottom layer.

\section{Molecular Orientation of the Peptide SAMs}

The amide I and II regions in the FTIR-RAS spectrum of the Nunchaku peptide SAM are shown in Figure 4. The average tilt angle of the helices was 

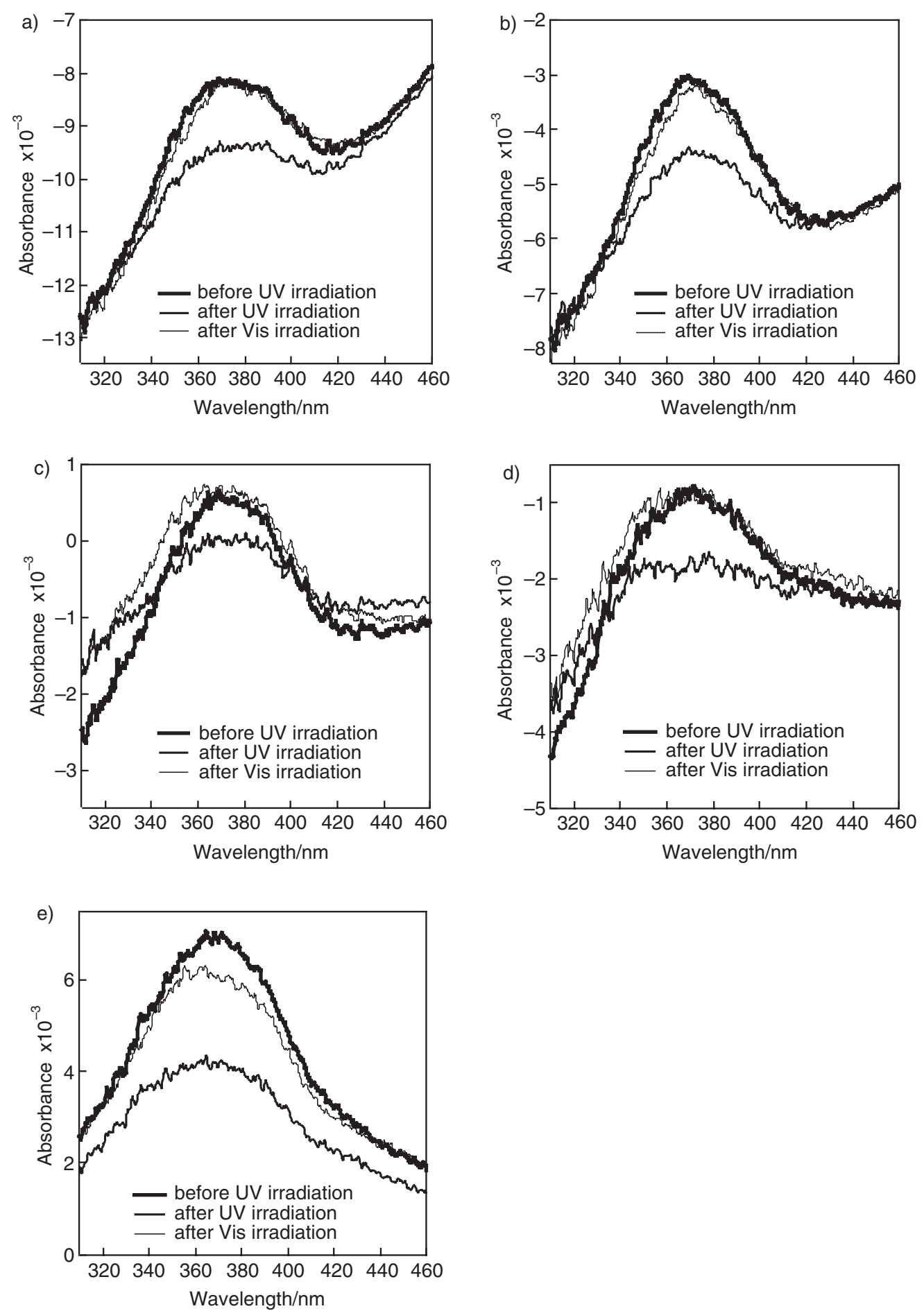

Figure 3. UV-vis absorption spectral change of the peptide SAMs; a) Nunchaku peptide SAM, b) Nunchaku Type-L SAM, c) AzL16SS SAM, d) Nunchaku peptide/SSL16B SAM, and e) Nunchaku Type-L/SSL16B SAM; before UV irradiation (thick lines), after UV irradiation (intermediate), and after Vis irradiation (thin lines).

estimated from the intensity ratio of amide I and II, and the result is summarized in Table I together with the tilt angles of the other SAMs.

Notably, the helices in the peptide SAMs take a vertical orientation on gold. Especially, the mixed SAMs showed the small tilt angles among these SAMs. In the mixed SAMs, the direction of the dipole moment of SSL16B is opposite to that of Nunchaku peptide or Nunchaku Type-L. The helices in the mixed SAM therefore can align tightly without suffering electrostatic repulsion due to the dipole moment, when SSL16B and Nunchaku peptide or Nunchaku Type-L molecules stand side by side on gold. This result is in good agreement with the previous report by Fujita et al. ${ }^{11}$ 


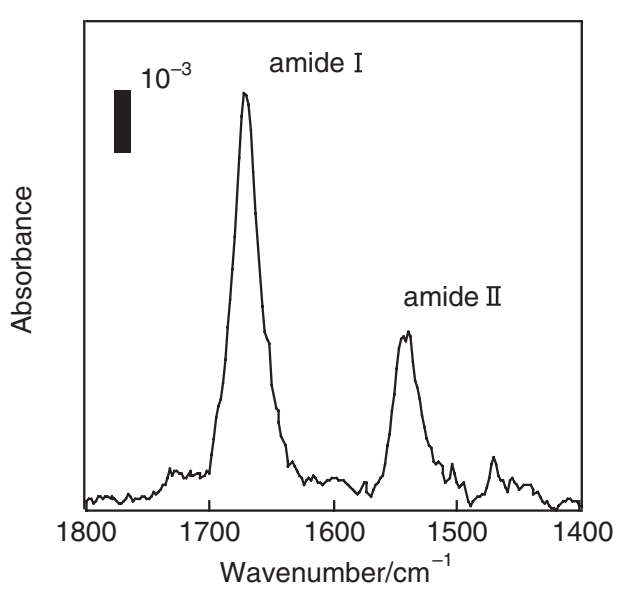

Figure 4. FTIR-RAS spectrum of the Nunchaku peptide SAM.

Table I. The ratio amide I/amide II absorbance and the tilt angle $(\gamma$, degree) of the peptide SAMs

\begin{tabular}{lcc}
\hline \multicolumn{1}{c}{ SAM } & $D_{\text {obs }}$ & $\gamma$ \\
\hline Nunchaku & 2.38 & 44 \\
Nuchaku type-L & 3.25 & 37 \\
AzL16SS & 2.14 & 49 \\
Nunchaku/SSL16B & 4.68 & 29 \\
Nunchaku type-L/SSL16B & 6.42 & 23 \\
\hline
\end{tabular}

\section{Surface Potentials of the SAMs}

True surface potentials of the peptide SAMs are usually difficult to obtain because the surface is contaminated by various adsorbates due to the electrostatic interaction. A baking process under high vacuum usually is effective to remove these adsorbates from the surface. In the present case, the SAMs were heated at $70^{\circ} \mathrm{C}$ for three hours under high vacuum, then were subjected to UV and visible light irradiation repeatedly. After this treatment on the SAMs, the photoresponse of the surface potential of the peptide SAM was recorded.

In either peptide SAM, positive surface potentials of $200-300 \mathrm{mV}$ were observed. The positive potentials can be explained from the fact that Nunchaku peptide, Nunchaku Type-L, and AzL16SS are immobilized on gold through the $\mathrm{C}$ terminal, and the positively charged $\mathrm{N}$ terminal is exposed to the surface in these peptide SAMs. The positive surface potentials of these peptide SAMs are also consistent with the previous report. ${ }^{12,13}$ However, the potential differences between the monocomponent SAMs and the mixed SAMs are relatively small, though SSL16B, which is connected to gold through $\mathrm{N}$ terminal, should partly cancel out the positively charged surface in the mixed SAMs. There are several reports which suggest that electrons are injected from gold to thin polyimide

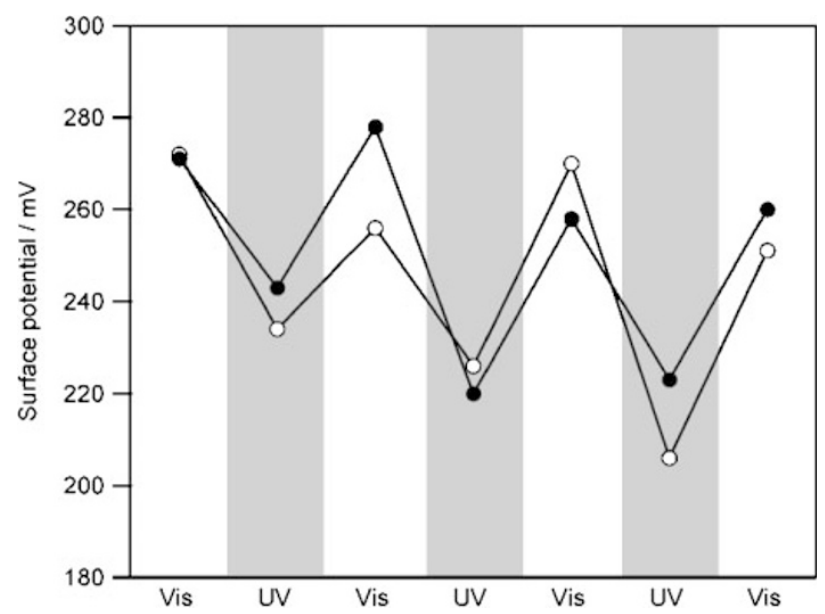

Figure 5. Change of surface potential upon photoirradiation: O; Nuncahku peptide SAM, ๑; Nunchaku Type-L SAM.

film or peptide layer deposited on gold. This effect may be the reason for the similar positive surface potentials between these peptide SAMs. ${ }^{12,13}$

In the case of the Nunchaku peptide SAM, UV irradiation decreased the surface potential by $30-60 \mathrm{mV}$, and the visible light irradiation increased the surface potential (Figure 5). Similarly, the surface potential of the Nunchaku Type-L SAM decreased by 20-30 $\mathrm{mV}$ upon UV irradiation, and increased upon visible light irradiation (Figure 5). On the other hand, the AzL16SS SAM, where the top helical peptide layer lacks, showed a constant surface potential irrespective of UV and visible light irradiation. These peptide SAMs were indicated to isomerize the azobenzene unit reversibly depending on the UV or visible light irradiation as described before. Therefore, the surface potential change of the Nunchaku peptide and the Nunchaku Type-L SAMs upon light irradiation should be due to the molecular orientation change of the helices in the top layer but not due to the helices in the bottom layer adjacent to gold nor the azobenzene unit.

This explanation is evidenced spectroscopically by PM-IRRAS measurements about the orientation change upon light irradiation on the SAMs. When the Nunchaku peptide SAM was irradiated by UV and visible light, the intensity ratio of amide I and II bands decreased upon UV irradiation and reversibly increased to the original level upon visible light irradiation (Figure 6). The same result was obtained with the Nunchaku Type-L SAM. The effects of the light irradiation on the intensity ratio of amide I and II bands and the tilt angles are summarized in Table II. The absorbance $\left(\mathrm{D}_{\mathrm{obs}}\right)$ changes reversibly upon photoirradiation in the cases of the Nunchaku peptide SAM and the Nunchaku Type-L SAM (Tables IIa, b).

On the other hand, in the cases of the mixed SAMs, the photoresposive behavior was not apparently 

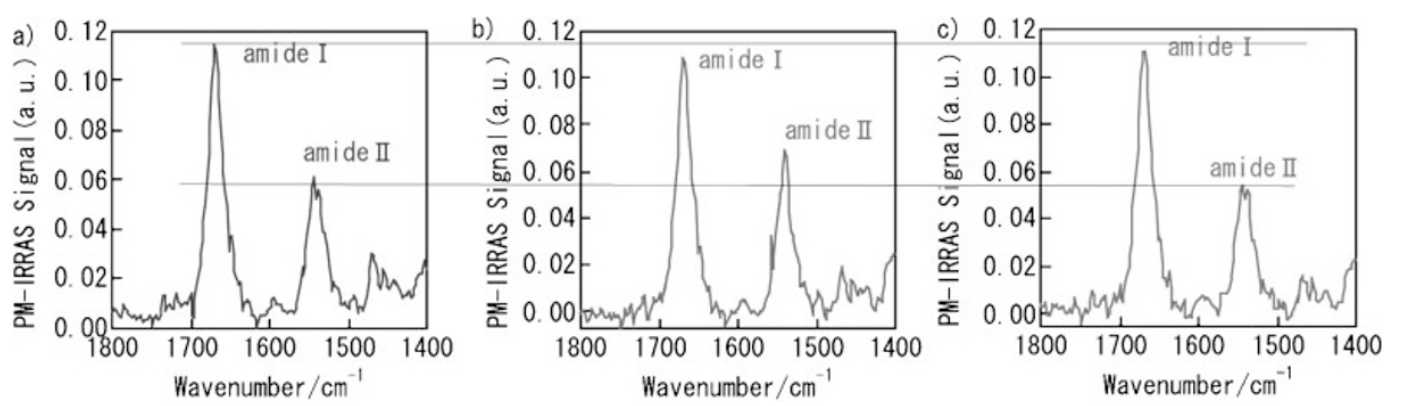

Figure 6. The Change of PM-IRRAS spectrum of the Nunchaku peptide SAM upon photoirradiation; a) before UV irradiation b) after UV irradiation c) after Vis irradiation.

Table II. The spectral change of amide I/amide II absorbance and the tilt angle ( $\gamma$, degree) upon photoirradiation; a) Nunchaku peptide SAM; b) Nunchaku Type-L SAM; c) Nunchaku/SSL16B SAM d) Nunchaku Type-L/SSL16B SAM

\begin{tabular}{|c|c|c|c|}
\hline \multirow[t]{4}{*}{ a) } & Nunchaku peptide SAM & $\mathrm{D}_{\mathrm{obs}}$ & $\gamma$ \\
\hline & before UV irradiation & 2.1 & 47 \\
\hline & after UV irradiation & 1.6 & 53 \\
\hline & after Vis irradiation & 2.0 & 48 \\
\hline \multirow[t]{4}{*}{ c) } & Nunchaku/SSL16B SAM & $\mathrm{D}_{\mathrm{obs}}$ & $\gamma$ \\
\hline & before UV irradiation & 3.7 & 34 \\
\hline & after UV irradiation & 3.4 & 36 \\
\hline & after Vis irradiation & 3.5 & 35 \\
\hline
\end{tabular}

\begin{tabular}{|c|c|c|c|}
\hline \multirow[t]{4}{*}{ b) } & Nunchaku Type-L SAM & $\mathrm{D}_{\mathrm{obs}}$ & $\gamma$ \\
\hline & before UV irradiation & 3.2 & 37 \\
\hline & after UV irradiation & 2.7 & 40 \\
\hline & after Vis irradiation & 3.1 & 38 \\
\hline \multirow[t]{4}{*}{ d) } & Nunchaku Type-L/SSL16B SAM & $\mathrm{D}_{\text {obs }}$ & $\gamma$ \\
\hline & before UV irradiation & 5.2 & 27 \\
\hline & after UV irradiation & 5.4 & 26 \\
\hline & after Vis irradiation & 5.8 & 25 \\
\hline
\end{tabular}

observed. The Nunchaku/SSL16B SAM increased the surface potential upon UV irradiation, and decreased upon visible light irradiation in some cases. But, this response was lost after repeating cycles of UV and visible light irradiation. The Nunchaku Type-L/ SSL16B SAM did not show a regular photoresponse neither. In the cases of the mixed SAMs, the helices in the top layer are loosely packed due to the presence of the spacing SSL16B in the bottom layer. These helices therefore may adopt various orientations upon photoisomerization of the azobenzene unit. Indeed, the average tilt angles of the helices did not show photoresponsive changes (Tables IIc and d), although the photoisomerization of the azobenzene unit occurred (Figure 3).

The helices are difficult to change the molecular orientation in the Nunchaku peptide SAM and the Nunchaku Type-L SAM as shown by the suppressed cis contents upon UV irradiation (Figure 3). The tight molecular packing in these peptide SAMs should hinder the alterations of the molecular orientation. However, when the helices in the monocomponent SAMs change the molecular orientation upon photoirradiation, the helices move in a cooperative manner to change the average tilt angles and the surface potentials. This cooperativity was lost in the mixed SAMs due to the free space generated by the presence of the spacing peptides without the azobenzene unit.

\section{CONCLUSIONS}

Helix-azobenzene-helix peptides were immobilized on gold with a vertical orientation. Upon photoirradiation of UV and visible light, the surface potential of the peptide SAMs reversibly changed due to the orientation change of the helices. The helices are tightly packed in the SAM, which should allow the cooperative movement of the helices upon photoirradiation. Cooperativity should be one of the characteristics of the peptide SAM.

\section{REFERENCES}

1. Ulman, "An Introduction to Ultrathin Organic Films from Langmuir-Blodgett to Self-Assembly," Academic Press, Boston, 1991.

2. M. Schultz, Nature, 399, 729 (1999).

3. S. Yasutomi, T. Morita, Y. Imanishi, and S. Kimura, Science, 304, 1944 (2004).

4. a) W. G. J. Hol, Prog. Biophys. Mol. Biol., 45, 149 (1985). b) G. Alegria and P. L. Dutton, Biochim. Biophys. Acta, 1057, 239 (1991).

5. a) Y. Miura, S. Kimura, Y. Imanishi, and J. Umemura, Langmuir, 14, 6935 (1998).

b) T. Morita, S. Kimura, S. Kobayashi, and Y. Imanishi, J. Am. Chem. Soc., 122, 2850 (2000).

c) T. Morita and S. Kimura, J. Am. Chem. Soc., 125, 8732 
(2003).

6. a) Y. Miura, S. Kimura, S. Kobayashi, M. Iwamoto, Y. Imanishi, and J. Umemura, Chem. Phys. Lett., 315, 1 (1999). b) Y. Imanishi, N. Kawazoe, and K. Ichizawa, J. Polym. Sci., Polym. Chem. Ed., 41, 3632b (2003).

7. K. Otoda, S. Kimura, and Y. Imanishi, Biochim. Biophys. Acta, 1145, 33 (1993).

8. M. Iwamoto, Y. Yoneda, and A. Fukuda, Jpn. J. Appl. Phys., 31, 3671 (1992).

9. D. Wu and R. A. Talham, Langmuir, 16, 7449 (2000).

10. a) M. J. Cook, A. M. Nygard, Z. Wang, and D. A. Russell,
Chem. Commun., 1056 (2002).

b) Z. Wang, M. J. Cook, A. M. Nygard, and D. A. Russell, Langmuir, 19, 3779 (2003).

11. K. Fujita, N. Bunjes, K. Nakajima, M. Hara, H. Sasabe, and W. Knoll, Langmuir, 14, 6167 (1998).

12. a) A. G. Knapp, Surf. Sci., 34, 289 (1973).

b) E. Ito and M. Iwamoto, J. Appl. Phys., 81, 1790 (1997).

c) G. M. Sessler, J. Appl. Phys., 43, 405 (1972).

13. Y. Miura, G.-C. Xu, S. Kimura, S. Kobayashi, M. Iwamoto, Y. Imanishi, and J. Umemura, Thin Solid Films, 393, 59 (2001). 